\title{
KAJAN EFEKTIVITAS PENGELOLAAN ZAKAT SEBAGAI SUATU USAHA UNTUK PEMBERDAYAAN MASYARAKAT DAN PENGENTASAN KEMISKINAN DI KOTA PADANG
}

\author{
Dr. H. Yuskar, SE, MA, AK, CA. \\ Universitas Andalas
}

Abstract

The study is a current survey aims to answer some of the concerns regarding the level of understanding and practice of compulsory charity (muzzaki) on his obligation to pay alms in accordance with the guidance of Islam, alms management effectiveness by $B A Z$ / LAZ by applying the principles of Good Governance Organization, so that the charity can act as community empowerment and poverty alleviation in the city of Padang. Data collection is done by spreading the questionnaires directly to the public compulsory alms ( muzzaki). Of the 150 respondents were given a list of questionnaires, only 105 questionnaires can be used. From the results of research conducted can be concluded that a mandatory public charity ( muzzaki) in Padang : a) understand the provisions of alms and tax laws in force; $b$ ) practice to fulfill their zakat obligation is very high; $c$ ) Understanding of the public on the benefits and effectiveness of the payment of zakat through BAZ / LAZ is quite high, but the realization of Padang city communities, are moyoritas make payments directly to mustahik zakat, and not many people through the Agency or amil zakat institutions exist; d) understanding and expectations high enough so that the organization alms ( $B A Z / L A Z$ ) can manage alms properly, effectively and economically, based on the principles of good organization covernance. $e$ ) high expectations and hopes for the community to BAZ / LAZ always be one tool in the business community empowerment and poverty alleviation .

Keywords : charity, BAZ/LAZ, empowerment, and poverty alleviation .

\section{PENDAHULUAN}

Di tengah-tengah masyarakat Indonesia terlihat nyata adanya permasalahan kesenjangan dalam penerimaan pendapatan masyarakat, ketidakadilan dan ketimpangan kesejahteraan dalam masyarakat. Situasi semacam ini, pada dasarnya akan dapat dicegah dan minimalisir melalui penerapan satu sistem pengelolaan pengumpulan zakat, pendistribusian dan penggunaan zakat secara tepat guna dan tepat sasaran, sesuai tuntunan dalam agama Islam dan juga dengan penerapan prinsip dan ilmu ekonomi, manajemen, akuntansi dan pengelolaan keuangan yang efektif dan efisien.

Di Kota Padang, dan juga banyak di tempat-tempat lain permasalahan berkaitan dengan zakat dan kemișkinan, dapat diidentifikasikan seperti, masih banyaknya orang Islam yang belum membayar zakat sesuai dengan jumlah yang seharusnya, membayar zakat kepada orang yang tidak berhak, sehingga tidak tepat guna dan sasaran. Di samping itu masih kurangnya jumlah Badan-Badan dan Lembaga-Lembaga Amil Zakat 
(BAZ/LAZ), yang tidak atau belum profesional sama sekali. Sehingga BAZ/LAZ tidak dapat menggerakan potensi dana zakat yang cukup besar di dalam masyarakat, melalui pengumpulan dana zakat secara maksimal dan juga belum dapat menggunakannya secara efisien dan efektif, sehingga harapan besar yang digantungkan kepada Badan-Badan Pengelola zakat, agar supaya dana zakat dapat berfungsi sebagai penyeimbang kesejehteraan, pengentasan kemiskinan, penciptaan lapangan kerja dan pemberdayaan masyarakat, baik dari sudut ekonomi dan juga dari sudut pengamalan ajaran Islam yang Kaffah, masih belum tercapai dan terwujudkan sampai sat ini.

Sebagaimana diketahui, bahwa Negara Indonesia merupakan negara yang memiliki keragaman agama dengan $75 \%$ lebih mayoritas rakyatnya memeluk Agama Islam, sehingga tak mengherankan apabila pemenuhan syariat bagi pemeluk agama islam memperoleh banyak kemudahan, salah satu diantaranya adalah mengenai pembayaran zakat. Hal ini ditandai dengan terbitnya Undang-undang Nomor 38 Tahun 1999 tentang Pengelolaan Zakat, dan pasal 9 ayat (1) huruf g Undang-undang Nomor 38 Tahun 2008 tentang Pajak Penghasilan yang mengatur mengenai ketentuan zakat sebagai pengurang penghasilan kena pajak.

Ekonomi islam merupakan sistem ekonomi yang berlandaskan Al-Qur'an dan Sunnah Rasul, di mana sangat menekankan pada nilai-nilai keadillan dan keseimbangan. Hal ini tercermin dari perhatian yang besar terhadap kaum yang lemah dengan menjamin dan melindungi kehidupan mereka. Islam menginginkan agar sistem ekonomi terorganisasi sedemikian rupa sehingga harta tidak hanya dalam genggaman orang kaya saja, namun dapat merata ke orang yang tidak mampu (QS. Al-Hasyr : 7).

Oleh karena itu, pendistribusian pendapatan melalui pengumpulan dan pembagian zakat haruslah dilakukan secara merata dan adil, sesuai dengan atruarn dan panduan dalam agama Islam. Untuk itu dibutuhkan pihak yang dapat mengurus zakat dengan baik, sehingga muncul lembaga zakat, infak dan sedekah, di mana orang yang kaya dapat memberikan zakatnya kepada orang yang berhak menerimanya, seperti fakir, miskin, mualaf, musyafir dan kaum dhuafa melalui lembaga tersebut (Muhammad dalam Widagdo, $2009: 2$ ).

Pengetahuan yang berkembang dari dulu dalam masyarakat kita mengenai zakat hanyalah berupa beras yang dikeluarkan seseorang pada akhir bulan Ramadhan sebesar $2,5 \mathrm{~kg}$, atau yang biasa disebut zakat fitrah. Padahal di dalam Al-Qur'an dan Hadist terdapat beragam pengaturan harta yang wajib untuk dikeluarkan zakatnya, termasuk zakat profesi.

Dalam Undang-undang Nomor 38 Tahun 1999 tentang pengelolaan zakat, disebutkan bahwa salah satu harta yang wajib dikeluarkan zakatnya ialah hasil pendapatan dan jasa. Bentuk zakat baru ini merupakan sebuah langkah maju dari hasil ijtihad para ulama sekarang.

Munculnya beberapa lembaga amil zakat baru-baru ini memberi angin segar bagi masyarakat muslim guna memenuhi kebutuhanya akan berzakat yang merupakan implementasi dari ketakwaan seorang muslim kepada Tuhannya. Pengelolaanya pun telah mengalami banyak kemajuan sehingga apabila hal ini terus berlanjut, ditambah lagi dengan bertambah banyaknya kesadaran masyarakat muslim untuk memenuhi kewajibannya untuk berzakat, maka dana zakat akan menjadi pilar kesejahteraan dalam 
berbangsa dan bernegara. Namun, ternyata hal itu tidaklah semudah membalikkan telapak tangan, sebagaimana telah diketahui bahwa bangsa Indonesia bukanlah negara yang menganut sistem syariat islam dalam menjalankan roda pemerintahan, maka bukan zakat yang dipakai sebagai acuan dalam melakukan penarikan iuran dari warganegaranya, melainkan berbagai bentuk pajak sesuai dengan Undang-Undang Perpajakan yang berlaku.

Dengan demikian, permasalahan yang muncul adalah berupa, adanya dua macam kewajian iuran yang menyebabkan umat islam memikul kewajiban yang lebih berat dibandingkan umat non-muslim. Di satu sisi, umat islam memiliki kewajiban atas zakat sebagai wujud ketakwaan kepada Allah SWT, dan di sisi lainnya juga wajib membayar pajak sebagai wujud kepatuhan kepada negara (Nurdin Mhd. Ali dalam Widagdo, 2009: 7). Hal ini memunculkan berbagai penafsiran pada pelaksanaan keduanya di kalangan umat Islam, antara lain:

a. Membayar kewajiban pajak dan zakat sekaligus dengan risiko jumlah harta yang dikeluarkan menjadi lebih besar

b. Menyamakan begitu saja antara pajak dengan zakat, dalam arti ia membayar pajak yang diniatkan untuk menunaikan kewajiban zakat

c. Membayar zakat tanpa mempedulikan pajak dengan risiko melanggar peraturan perundang-undangan yang berlaku.

Pemahaman masyarakat yang masih kurang terhadap kewajiban zakat, dan adanya perasaan kewajiban ganda umat Islam dibanding dengan umat non Islam telah mendorong pemerintah dan legislatif untuk menghadirkan atau membuat Undang-undang Nomor 17 Tahun 2000 sebagai penyempurnaan dari Undang-undang Nomor 38 Tahun 2008 pasal 9 ayat (1) huruf $g$ yang mana menyebutkan bahwa "pembayaran zakat merupakan pengurang penghasilan kena pajak". Hai ini mungkin mampu menjadi solusi sementara bagi umat muslim dalam pembayaran kewajiban zakat dan pajak.

Dari uraian di atas, serta untuk lebih mengetahui sejauh mana tingkat pemahaman wajib zakat dan wajib pajak orang pribadi di Kota Padang dan efektifnya pengelolaan zakat di Kota Padang, lebih lanjut kami melakukan penelitian megenai efektivitas pengelolaan zakat dan dan perannya dalam usaha permberdayaan masyarakat dan pengentasan kemiskinan di kota Padang.

Berdasarkan uraian tersebut, secara terinci dapat dirumuskan beberapa masalah penelitian ini seperti berikut: (a).Bagaimana tingkat pemahaman dan pengamalan wajib zakat (muzzaki) orang pribadi terhadap kewajibannya membayarkan zakat? (b).Bagaimana tingkat pemahaman wajib zakat (muzzaki) tentang manfaat dan efektifitas pembayaran zakat profesi atau zakat penghasilan melalui BAZ/LAZ?. (c).Bagaimana pengelolaan zakat yang lebih baik oleh BAZ/LAZ dengan menerapkan prinsip-prinsip Good Organization Governance?. (d).Bagaimana peran BAZ/LAZ untuk meningkatkan pemahaman dan pengamalan pembayaran zakat oleh masyarakat (muzzaki)?, terutama pembayaran melalui BAZ/LAZ?.(e).Bagaimana pemahaman masyarakat tentang adanya aturan Undang-Undang bahwa pembayaran zakat melalui BAZ/LAZ dapat mengurangi jumlah penghasilan kena Pajak (PTKP)?. (f).Bagaimana keinginan masyarakat tentang perlu adanya Undang-Undang yang memperlakukan zakat yang dibayarkan melalui $\mathrm{BAZ} / \mathrm{LAZ}$ sebagai pengurangan atas jumlah pajak penghasilan yang terhutang? 
Sedangkan tujuan penelitian adalah sebagai berikut: (a). Tingkat pemahaman dan pengamalan wajib zakat (muzzaki) orang pribadi terhadap kewajibannya membayarkan zakat. (b). Tingkat pemahaman wajib zakat (muzzaki) orang pribadi akan manfaat dan efektivifnya pembayaran zakat profesi atau zakat penghasilan melalui BAZ/LAZ (c).Pengelolaan zakat yang lebih baik dan efektif oleh BAZ/LAZ dengan menerapkan prinsip-prinsip Good Organization Governance. (d).Peran BAZ/LAZ untuk meningkatkan pemahaman dan pengamalan pembayaran zakat oleh masyarakat (muzzaki)?, terutama pembayaran melalui BAZ/LAZ. (e).Bagaimana pemahaman masyarakat tentang adanya aturan Undang-Undang bahwa pembayaran zakat melalui BAZ/LAZ dapat mengurangi jumlah penghasilan kena Pajak (PTKP). (f).Keinginan masyarakat akan adanya Undang-Undang yang memperlakukan zakat yang telah dibayarkan muzzaki melalui BAZ/LAZ, sebagai pengurangan atas jumlah pajak penghasilan yang terhutang?

Penelitian ini diharapkan bermanfaat untuk berbagai pihak, yaitu: (a). Bagi masyarakat, dapat memberikan informasi dan pemahaman yang lebih baik kepada masyarakat (muzzaki) serta mendorong mereka untuk dapat menunaikan kewajiban zakat dan kewajiban pajaknya secara lebih sempurna. (b).Bagi peneliti lanjutan, dapat menjadi dasar untuk melakukan penelitian lanjutan dalam usaha pengembangan dan peningkatan peran zakat sebagai alat untuk pengentasan kemiskinan. (c).Bagi Manajemen BAZ\&LAZ, hasil penelitian ini dapat menjadi bahan pertimbangan dalam peningkatan dan penyempurnaan tatacara pengelolaan zakat yang lebih efektif. (d).Bagi pihak Legislatif, hasil penelitian ini dapat menjadi bahan masukan bagi DPR/pihak legislatif untuk membuat aturan perundang-undangan yang dpat memperlakukan zakat profesi/penghasilan sebagai pengurangan atas jumlah pajak pengahasilan yang terhutang bagi wajib pajak dan sekaligus ia juga sebagai wajib zakat. (e).Bagi Peneliti sendiri, diharapkan penelitian ini dapat memperluasan wawasan dan pengetahuan, serta meningkatkan pengamalan tentang kewajiban zakat dan pajak penghasilan sebagai umat Islam dan Warga Negara Republik Indonesia.

\section{2.}

\subsection{Pengertian Zakat}

Istilah zakat bermakna tumbuh, bersih, berkembang, dan berkah. Sedangkan menurut terminologi syariat Islam, zakat berarti kewajiban atas sejumlah harta tertentu yang telah mencapai syarat tertentu yang diwajibkan dalam agama Islam untuk dikeluarkan dan diberikan kepada yang berhak menerimanya dengan persyaratan tertentu pula. Kewajiban tersebut dikenakan kepada setiap muslim ketika mereka memiliki sejumlah harta yang sudah memenuhi batas nisabnya.

Sebagian umat Islam yang menjadi wajib zakat (muzzaki) sekaligus juga sebagai wajib pajak, menganggap dan menyamakan antara zakat dan pajak, sehingga konsekuannya ketika seseorang telah membayar pajak maka gugurlah pembayaran zakatnya. Sebaliknya pemahaman, yang benar haruslah membedakan antara kewajiban membayar zakat dan kewajiban membayar pajak penghasilan, karena kedua-duanya zakat dan pajak memiliki karakteristik berbeda.

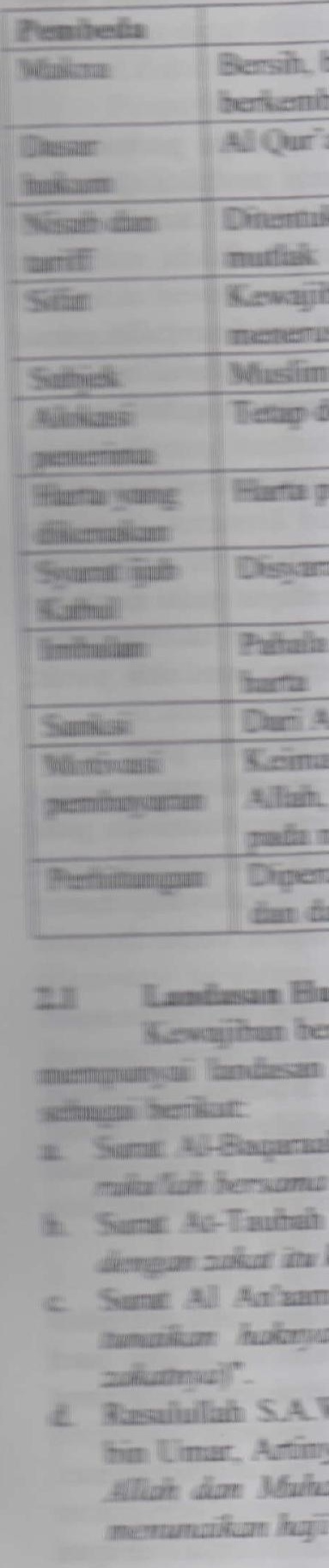

4 
Tabel 2.1

Perbedaan antara Zakat dan Pajak

\begin{tabular}{|l|l|l|}
\hline Pembeda & \multicolumn{1}{|c|}{ Zakat } & \multicolumn{1}{c|}{ Pajak } \\
\hline Makna & $\begin{array}{l}\text { Bersih, bertambah, dan } \\
\text { berkembang }\end{array}$ & Utang, pajak, upeti \\
\hline $\begin{array}{l}\text { Dasar } \\
\text { hukum }\end{array}$ & Al Qur'an dan Sunnah & Undang-undang suatu Negara \\
\hline $\begin{array}{l}\text { Nisab dan } \\
\text { tariff }\end{array}$ & $\begin{array}{l}\text { Ditentukan Allah dan bersifat } \\
\text { mutlak }\end{array}$ & $\begin{array}{l}\text { Ditentukan negara dan bersifat } \\
\text { relative }\end{array}$ \\
\hline Sifat & $\begin{array}{l}\text { Kewajiban bersifat tetap dan terus } \\
\text { menerus }\end{array}$ & $\begin{array}{l}\text { Kewajiban sesuai kebutuhan dan } \\
\text { dapat dihapuskan }\end{array}$ \\
\hline Subjek & Muslim & Semua warga Negara \\
\hline $\begin{array}{l}\text { Alokasi } \\
\text { penerima }\end{array}$ & Tetap delapan golongan & $\begin{array}{l}\text { Sebagai dana pembangunan dan } \\
\text { anggaran rutin negara }\end{array}$ \\
\hline $\begin{array}{l}\text { Harta yang } \\
\text { dikenakan }\end{array}$ & Harta produktif & Semua harta \\
\hline $\begin{array}{l}\text { Syarat ijab } \\
\text { Kabul }\end{array}$ & Disyaratkan & Tidak disyaratkan \\
\hline Imbalan & $\begin{array}{l}\text { Pahala dari Allah dan keberkahan } \\
\text { harta }\end{array}$ & $\begin{array}{l}\text { Tersedianya barang dan jasa } \\
\text { public }\end{array}$ \\
\hline Sanksi & Dari Allah dan pemerintah Islam & Dari Negara \\
\hline $\begin{array}{l}\text { Motivasi } \\
\text { pembayaran }\end{array}$ & $\begin{array}{l}\text { Keimanan dan ketakwaan kepada } \\
\text { Allah, ketaatan dan ketakutan } \\
\text { pada negara dan sanksinya }\end{array}$ & $\begin{array}{l}\text { Ada pembayaran pajak } \\
\text { dimungkinan adanya menipulasi } \\
\text { besarnya jumlah harta wajib pajak }\end{array}$ \\
\hline Perhitungan & $\begin{array}{l}\text { Dipercayakan kepada muzzaki } \\
\text { dan dapat juga dengan bantuan }\end{array}$ & $\begin{array}{l}\text { Selalu menggunakan jasa akuntan } \\
\text { pajak }\end{array}$ \\
\hline
\end{tabular}

\subsection{Landasan Hukum Kewajiban Zakat}

Kewajiban berzakat sudah dimulai di zaman Rasullullah Muhammad S.A.W. dan mempunyai landasan hukum yang kuat, berupa Al Qur'an, sunnah, dan ijma' ulama, sebagai berikut:

a. Surat Al-Baqaraah ayat 43, Artinya: "Dirikanlah shalat dan tunaikanlah zakat dan ruku'lah bersama dengan orang-orang yang ruku."

b. Surat At-Taubah ayat 103, Artinya: "Ambillah zakat dari sebagian harta mereka, dengan zakat itu kamu membersihkan dan mensucikan mereka..."

c. Surat Al An'aam ayat 141, Artinya: "Makanlah buahnya jika telah berbuah dan tunaikan haknya (kewajibannya) dihari memetik hasilnya (dengan dikeluarkan zakatnya)".

d. Rasulullah S.A.W bersabda yang diriwayatkan Bukhari dan Muslim dari Abdullah bin Umar, Artinya: "Islam dibangun atas lima rukun: Syahadat tiada Tuhan kecuali Allah dan Muhammad S.A.W utusan Allah, menegakkan shalat, membayar zakat, menunaikan haji dan puasa di bulan Ramadhan". 
e. Hadist diriwayatkan oleh Ath-Thabrani dari Ali R.A, Artinya: “... Allah mewajibkan (zakat) atas orang-orang kaya dari umat Islam pada harta mereka dengan batas sesuai kecukupan fuqoro' diantara mereka...".

\subsection{Syarat Harta yang Wajib Dizakati}

Harta yang akan dikeluarkan zakatnya harus memenuhi beberapa persyaratan, yaitu: (a).Dimiliki penuh dan berkuasa menggunakannya. (b).Harta produktif (Nama). (c).Mencapai nisab (standar minimal harta yang dikenakan zakat). (d).Surplus dari kebutuhan primer dan terbebas dari utang. (e).Sudah berlalu setahun (Haul)

\subsection{Jenis Zakat}

Pada dasarnya hanya terdapat dua macam zakat, yaitu zakat mal (harta) dan zakat fitrah yang dibayarkan pada akhir bulan ramadhan hingga saat menjelang shalat hari raya idul fitri. Berbeda dengan zakat mal, zakat fitrah diwajibkan atas setiap orang, bukan atas kekayaan.

Menurut ijtihad para ulama, zakat mal dapat terbagi sebagai berikut:

1. Berdasarkan Al Qur'an dan Sunnah

a. Zakat emas dan perak

Dasar hukum yang mewajibkan zakat emas dan perak terdapat pada surat At Taubah ayat $34-35$, “...Dan orang-orang yang menyimpan emas dan perak dan tidak menafkahkannya pada jalan Allah...". Ayat ini memaksudkan bahwa emas dan perak dalam artian uang merupakan sesuatu yang dapat disimpan dan diinfakkan.

Nisab zakat emas adalah 20 dinar atau kira-kira setara dengan 85 gram emas murni. Sedangkan nisab perak adalah 200 dirham atau setara dengan 643 gram perak. Kadar zakat yang dikeluarkan dari emas dan perak adalah 2,5\%. Dengan demikian, jika seseorang memiliki 20 dinar dan telah mencapai masa satu tahun (satu haul), maka zakat yang harus dikeluarkan adalah 1 dinar. Atau dari 200 dirham, zakat yang harus dikeluarkan adalah 5 dirham.

b. Zakat tanaman atau pertanian

Dasar hukum yang mewajibkan zakat pertanian ini terdapat pada Al Qur'an surat Al An'am ayat 141, “...dan tunaikanlah haknya di hari memetik hasilnya (dengan disedekahkan kepada fakir miskin)...". Nisab hasil pertanian adalah 5 wasaq atau setara dengan $653 \mathrm{~kg}$ dari hasil pertanian tersebut dan dikeluarkan zakatnya saat panen. Penentuan kadar zakat hasil pertanian adalah sebesar $10 \%$ jika pengairan menggunakan air hujan dan sebesar 5\% jika menggunakan alat atau memindahkan air dari tempat lain dengan kendaraan dan alat lainnya.

c. Zakat perdagangan atau perniagaan

Barang atau aset perniagaan merupakan aset yang dipersiapkan untuk transaksi jual beli dan mencari keuntungan. Dasar hukum yang mewajibkan zakat atas aset perniagaan terdapat dalam Al qur'an surat Al Baqarah ayat 267, "Hai orang-orang yang beriman, nafkahkanlah (di jalan Allah) sebagian dari usahamu yang baik-baik."

Cara mengeluarkan zakat perniagaan adalah dengan menentukan waktu tahunan untuk membayar zakat. Pada saat itu, pemilik harus menghitung modal yang dipersiapkan untuk perdagangan, yaitu harga jual barang sewaktu membayar zakat ditambah dengan sisa uang kas yang masih ada di tangan. Kemudian dikurangi dengan kewajibannya. 
Zakat $=2,5 \% \times\{($ Aset perniagaan + Sisa uang kas di tangan atau laba $)-$ kewajiban $\}$

Aset berupa peralatan dan bangunan yang tidak digunakan untuk kegiatan perdagangan dapat dikeluarkan dari perhitungan aset yang dikeluarkan zakatnya.

d. Zakat hewan ternak

Pengertian hewan ternak yang wajib dikeluarkan zakatnya adalah hewan yang dimanfaatkan oleh manusia, seperti unta, lembu, dan kambing. Dasar hukum yang mewajibkan zakat hewan ternak adalah hadist nabi yang memerintahkan untuk mengeluarkan zakat atas hewan ternak yang dimiliki. Syarat umum hewan yang dizakatkan adalah mencapai nisab, mencapai haul, merupakan hewan yang digembalakan, dan bukan hewan yang digunakan untuk bekerja, seperti membajak sawah atau membawa

barang.Macam-macam hewan ternak yang dizakatkan adalah unta, lembu dan kambing.
e. Zakat barang temuan dan barang tambang (rikaz). Barang membedakan makna antara barang tambang (galian) dan barang temuan
Allah, baik berbentuk adalah semua yang berasal dari perut bumi yang diciptakan Allah, baik berbentuk padat maupun cair. Sedangkan rikaz adalah harta pendaman zaman jahiliyyah, termasuk barang yang ditemukan di atas permukaan bumi. Zakat yang harus dikeluarkan dari harta barang tambang adalah sebanyak $2,5 \%$, sedangkan untuk barang temuan (rikaz) adalah $20 \%$. Dalam barang tambang dikenakan nisab, sedangkan untuk
barang temuan tidak berlaku.

\section{Berdasarkan Ijtihad para Ulama}

a. Zakat mata uang

Dr. Yusuf Qardawy dalam Syamsun Nahar $(2004: 32)$ menegaskan berdasarkan pendapat mayoritas mahzab bahwa uang kertas pada saat ini memiliki peran sebagaimana yang dijalankan oleh mata uang emas dan perak, maka apa yang disyariatkan atas uang emas dan perak juga berlaku pada uang kertas selama uang tersebut berlaku di masyarakat sebagai alat tukar. Nisab zakat uang adalah sebesar 5 awqiyah, dimana satu awqiyah setara dengan 40 dirham. Maka, nisab uang perak adalah 200 dirham yang jika dikonversi ke dalam satuan yang dipakai dunia secara luas nisab perak sama nilainya dengan 595 gram perak.

Adapun tentang nisab uang emas, tidak ada hadits kuat yang mendasari. Namun, Jumhur berpendapat bahwa nisab emas adalah 20 dinar. Dr. Yusuf Qardawy dalam Syamsun Nahar (2004 : 33) mengatakan bahwa nisab emas sama dengan 85 gram emas. Dengan demikian, jika kepemilikan uang jenis apapun telah menyamai 85 gram emas,
maka wajib dikeluarkan zakatnya sebesar $2,5 \%$.

\section{b.Zakat utang piutang}

Menurut pendapat ulama yang rajih, seseorang yang memberi pinjaman kepada orang lain dan masa pinjaman berlalu beberapa waktu, maka orang yang memberi pinjaan harus mengeluarkan zakat piutang dalam jangka waktu setahun saja meskipun utang tersebut berlalu bertahun-tahun. Zakat yang wajib dikeluarkan sebesar $2,5 \%$ dari nilai pinjaman/piutang.

c. Zakat penghasilan, Zakat penghasilan merupakan istilah baru dalam fikih. Jenis zakat ini merupakan
hasil pendapat dari ulama-ulama kontemporer, seperti, Abdullah bin Baaz, dan Syeikh Muhammad Shalih al-Utsaimin.Zakat penghasilan adalah zakat yang dikenakan pada 
setiap pekerjaan atau keahlian profesional tertentu, baik yang dilakukan sendiri maupun bersama dengan orang dan lembaga lain, yang mendatangkan penghasilan. Zakat penghasilan dikenakan pada setiap kelebihan harta yang diperoleh melalui usaha atau kerja yang halal setelah dikurangi kebutuhan pokok sehari-hari. Nisab zakat penghasilan adalah sebesar 85 gram emas dan telah cukup berlalu setahun (haul). Kadar zakat penghasilan adalah $2,5 \%$.

d.Zakat saham dan surat berharga

Para ulama sepakat bahwa hukum menginvestasikan harta melalui pembelian dan pemilikan saham adalah sah secara syar'i dan keuntungannya wajib dizakatkan. Keuntungan atau kerugian perusahaan dapat diketahui pada saat Rapat Umum Pemegang Saham (RUPS) dan pada saat itulah zakat diwajibkan.

e. Zakat perhiasan wanita

Pengenaan zakat perhiasan tidak dimaksudkan untuk perhiasan yang biasa dipakai oleh perempuan, namun lebih ditekankan pada perhiasan yang sengaja disimpan, melebihi ambang kewajaran, perhiasan laki-laki, atau untuk bejana, hadiah, dan sebagainya. Perhiasan-perhiasan tersebut dikenakan zakat dengan kadar zakat sebesar $2,5 \%$.

f. Zakat apartemen, perkantoran, dan barang persewaan

Jenis zakat ini lebih menekankan pada pemilikan apartemen, perkantoran, rumah, bangunan lain, kendaraan, atau pabrik yang disewakan dan tidak digunakan untuk konsumsi primer. Adapun cara mengeluarkan zakatnya adalah dengan menghitung hasil dari persewaan tersebut, kemudian dikeluarkan zakatnya sebesar $2,5 \%$ jika telah mencapai nisab (dalam hal ini adalah nisab emas).

g. Zakat madu lebah

Zakat madu hukumnya wajib menurut mahzab Hanbali dan Hanafi. Dasar hukumnya adalah beberapa hadits Rasulullah dan para sahabat, diantaranya adalah yang diriwayatkan oleh Abu Daud dan An Nasa'i, “...Jika ia membayar sepersepuluh yang pernah ia berikan di masa Rasulullah, maka silakan ia menjaga lembah Salbah, jika tidak maka sesungguhnya mereka itu lebah hujan yang dimakan oleh siapa saja. "Persentase zakat madu adalah sebesar $10 \%$ dari hasil madu setelah dikurangi biaya produksi.

Menurut Abu Hanifah dalam Syamsun Nahar (2004:39), tidak ada nisab zakat madu, tetapi diambil zakatnya berapapun jumlahnya. Sedangkan menurut Abu Yusuf, nisabnya adalah senilai 5 wisq, yaitu nisab terkecil barang-barang yang dapat ditimbang.

h.Zakat hasil laut dan perikanan

Zakat ini dikenakan jika hasil laut dan perikanan digunakan untuk dijual. Nisab zakat ini sama seperti dikenakan terhadap nisab uang. Kadar zakat laut dan perikanan adalah sebesar $2,5 \%$.

\subsection{Penerima Zakat}

Zakat hanya diperuntukkan bagi delapan golongan (asnaf) saja. Dasar hukum yang dipakai adalah Al Qur'an surat At Taubah ayat 60, "Sesungguhnya zakat-zakat itu hanyalah untuk orang-orang kafir, orang-orang miskin, pengurus-pengurus zakat, para muallaf yang dibujuk hatinya, untuk memerdekakan budak, orang-orang yang berutang, 
untuk jalan Allah, dan orang-orang yang sedang dalam perjalanan, sebagai suatu ketetapan yang diwajibkan Allah; dan Allah Maha Mengetahui lagi Maha Bijaksana."

Delapan golongan penerima zakat tersebut adalah: (a).Orang fakir dan kekurangan. (b).Miskin. (c).Pengelola zakat. (d). Muallaf. (e).Pemerdekaan budak dan pembebasan sandera. (f).Membayar utang orang yang terlilit utang (gharim).(g).Jihad dan perang di jalan Allah (fisabilillah). (h). Orang yang sedang bepergian dan mendapat kecelakaan (ibnu sabil). Ibnu sabil adalah orang yang sedang bepergian yang tidak mampu melanjutkan perjalanan karena sedang kehabisan bekal, kehilangan, atau kecopetan, termasuk juga anak jalanan dan tunawisma.

\subsection{Pengelolaan Zakat}

Dengan berlakunya Undang-Undang Nomor 36 Tahun 2008 tentang Perubahan Keempat atas Undang-Undang Nomor 7 Tahun 1983 tentang Pajak Penghasilan, terjadi penyempurnaan terhadap hal-hal yang berkaitan dengan pajak penghasilan, yang sudah diatur undang-undang sebelumnya. Salah satunya adalah dimasukannya ketentuan yang berhubungan dengan pembayaran zakat. Diakomodasinya ketentuan mengenai zakat di dalam undang-undang Pajak Penghasilan, berkaitan dengan diberlakukannya UndangUndang Nomor 38 Tahun 1999 tentang Pengelolaan Zakat. Sehingga pengaturan ini sebenarnya merupakan tindak lanjut Undang-Undang Nomor 38 Tahun 1999 yang mengatur masalah pengelolaan zakat.

Lahirnya Undang-Undang Nomor 38 Tahun 1999 dilatarbelakangi oleh kenyataan sosiologis, bahwa masyarakat Indonesia mayoritas beragama Islam. Dimana Islam telah menentukan kewajiban-kewajiban yang harus dipatuhi oleh para penganutnya. Pelaksanaan kewajiban beragama ini dijamin dan dilindungi oleh negara sesuai dengan Pancasila sila pertama dan UUD 1945 pasal 29. Salah satu kewajiban tersebut yang mempunyai implikasi sangat luas terhadap kehidupan masyarakat adalah kewajiban untuk menunaikan zakat.

Zakat selain berdimensi sakral, juga memiliki dimensi moral, sosial, dan material-ekonomi. Oleh karena itu, pengumpulan zakat secara idealis dan praktis merupakan sumber dana potensial bagi upaya mewujudkan keadilan sosial dan kesejahteraan rakyat secara tidak langsung merupakan sumber dana investasi bagi perbaikan struktur sosial dan ekonomi negara yang akan menjadi lebih baik dengan adanya sumber dana dari zakat, minimal mengurangi kesenjangan sosial.

Ketentuan dalam Undang-undang Nomor 36 Tahun 2008 yang berkaitan dengan zakat dituangkan dalam 2 (dua) pasal atau persisnya 2 ayat dalam pasal yang berbeda, yaitu pasal pasal 4 (3) huruf a angka 1 dan pasal 9 (1) huruf g. Dimana menurut penjelasan pasal 4 (3) huruf a, yang dimaksud dengan zakat disini adalah zakat sebagaimana diatur dalam Undang-undang Nomor 38 Tahun 1999 tentang Pengelolaan Zakat. Lembaga yang secara formal diakui oleh Undang-Undang Nomor 38 Tahun 1999 sebagai lembaga yang berhak mengelola zakat adalah Badan Amil Zakat (BAZ) dan Lembaga Amil Zakat (LAZ). Oleh karena itu, kedua lembaga ini memiliki peran dan fungsi yang strategis, baik dilihat dari perspektif pemberdayaan sosial-ekonomi umat maupun dari hubungan zakat dengan perpajakan. 


\section{Undang-Undang Nomor 38 Tahun 1999}

Undang-undang ini sesuai dengan namanya, hanyalah mengatur soal "pengelolaan zakat", atau bagaimana zakat tersebut dikelola secara baik dan dapat dipertanggungjawabkan kepada masyarakat, bukan mengatur "zakat" itu sendiri. Artinya persoalan subyek, obyek, tarif zakat dan siapa yang berhak menerima zakat sudah diatur tersendiri dalam Sya'riat atau Fikih Islam. Sehingga wilayah atau otoritas UndangUndang Nomor 38 Tahun 1999 hanyalah sebatas pengaturan formal pengelolaan zakatnya.

Pengelolaan zakat menurut undang-undang no. 38 Tahun 1999, merupakan kegiatan perencanaan, pengorganisasian, pelaksanaan, dan pengawasan terhadap pengumpulan dan pendistribusian serta pendayagunaan zakat (pasal 1 angka 1). Sedangkan definisi zakat adalah harta yang wajib disisihkan oleh seorang muslim atau badan yang dimiliki oleh orang muslim sesuai dengan ketentuan agama untuk diberikan kepada yang berhak menerimanya (pasal 1 angka 2). Dimana jenis zakat terdiri dari zakat mal dan zakat fitrah (pasal 7 ayat 1).

Pengelolaan zakat dilakukan oleh Badan Amil Zakat (BAZ) yang dibentuk oleh pemerintah dan Lembaga Amil Zakat (LAZ) yang dikukuhkan, dibina dan dilindungi oleh Pemerintah (pasal 6 dan 7). Kedua lembaga ini tugas pokoknya adalah mengumpulkan, mendistribusikan, dan mendayagunakan zakat sesuai dengan ketentuan agama. Dalam melaksanakan tugasnya ini, BAZ dan LAZ bertanggung jawab kepada pemerintah sesuai dengan tingkatannya (pasal 9). Selain menerima pembayaran zakat seperti diutarakan sebelumnya, kedua lembaga ini dapat menerima seperti infaq, shadaqah, hibah, wasiat, waris, dan kafarat (pasal 13).

Undang-Undang Nomor 38 Tahun 1999 tentang Pengelolaan Zakat, pelaksanaannya selanjutnya diatur dengan Keputusan Menteri Agama Nomor 581 Tahun 1999 tentang Pelaksanaan Undang-Undang Nomor 38 Tahun 1999, dan Keputusan Direktur Jenderal Bimbingan Masyarakat Islam dan Urusan Haji Nomor D/291 Tahun 2000 tentang Pedoman Tekhnis Pengelolaan Zakat.

\subsubsection{Badan Amil Zakat(BAZ)}

Badan Amil Zakat adalah organisasi pengelola zakat yang dibentuk oleh pemerintah, yang terdiri dan unsur masyarakat dan pemerintah dengan tugas mengumpulkan, mendistribusikan dan mendayagunakan zakat sesuai dengan ketentuan agama.

\section{Pembentukan BAZ}

Pembentukan BAZ merupakan hak otoritatif pemerintah, sehingga hanya pemerintah yang berhak membentuk BAZ, baik untuk tingkat nasional sampai tingkat kecamatan. Semua tingkatan tersebut memiliki hubungan kerja yang bersifat koordinatif, konsultatif, dan informatif. Badan Amil Zakat dibentuk sesuai dengan tingkatan wilayahnya masing-masing.

2. Pengurus dan Unsur Organisasi BAZ

Pengurus BAZ terdiri atas unsur masyarakat dan pemerintah yang memenuhi persyaratan tertentu. Unsur dari masyarakat ini lebih lanjut dijelaskan dalam Keputusan Menteri Agama Nomor 581 Tahun 1999 tentang Pelaksanaan Undang-Undang Nomor 38 
Tahun 1999, yaitu unsur masyarakat terdiri dari ulama, kaum cendekia, tokoh masyarakat, dan tenaga profesional (pasal 2 ayat 2).

\section{Kewajiban BAZ}

Dalam melaksanakan seluruh kegiatannya Badan Amil Zakat memiliki kewajiban yang harus dilaksanakan, yaitu :

a. Segera melakukan kegiatan sesuai dengan program kerja yang telah dibuat.

b. Menyusun laporan tahunan, yang didalamnya termasuk laporan keuangan.

c. Mempublikasikan laporan keuangan tahunan yang telah diaudit oleh akuntan publik atau lembaga pengawas pemerintah yang berwenang melalui media massa sesuai dengan tingkatannya, selambat-lambatnya enam bulan setelah tahun buku terakhir.

d. Menyerahkan laporan tersebut kepada pemerintah dan Dewan Perwakilan Rakyat sesuai dengan tingkatannya.

e. Merencanakan kegiatan tahunan.

f. Mengutamakan pendistribusian dan pendayagunaan dari dana zakat yang diperoleh didaerah masing-masing sesuai dengan tingkatannya, kecuali BAZ Nasional dapat mendistribusikan dan mendayagunakan dana zakat ke seluruh wilayah Indonesia.

4. Pembubaran BAZ

Badan Amil Zakat dapat ditinjau ulang pembentukannya, apabila tidak melaksanakan kewajiban sebagaimana mestinya. Mekanisme peninjauan ulang terhadap BAZ tersebut melalui tahapan sebagai berikut :

a. Diberikan peringatan secara tertulis oleh Pemerintah sesuai dengan tingkatannya yang telah membentuk BAZ.

b. Bila peringatan telah dilakukan sebanyak 3 (tiga) kali dan tidak ada perbaikan, maka pembentukan dapat ditinjau ulang dan Pemerintah dapat membentuk kembali BAZ dengan susunan pengurus yang baru.

\subsubsection{Lembaga Amil Zakat (LAZ)}

Sebelum berlakunya undang-undang pengelolaan zakat, sebenarnya fungsi pengumpulan, pengelolaan, dan pendistribusian zakat telah eksis terlebih dahulu ditengah-tengah masyarakat. Fungsi ini dikelola oleh masyarakat sendiri, baik secara perorangan maupun kelompok (kelembagaan). Hanya saja dengan berlakunya undangundang ini, telah terjadi proses formalisasi lembaga yang sudah eksis tersebut.

Menurut undang-undang Nomor 38 Tahun 1999, Lembaga Amil Zakat adalah institusi pengelolaan zakat yang sepenuhnya dibentuk atas prakarsa masyarakat dan oleh masyarakat yang bergerak di bidang da'wah, pendidikan, sosial dan kemaslahatan umat Islam.

1. Pengesahan atau Pengukuhan LAZ

Untuk mendapat pengukuhan, sebelumnya calon LAZ harus mengajukan permohonan kepada Pemerintah sesuai dengan tingkatan Ormas Islam yang memilikinya dengan melampirkan syarat-syarat sebagai berikut :

a. Akte pendirian (berbadan hukum),

b. Data muzzaki (yang membayar zakat) dan mustahik (yang berhak menerima zakat, 
c. Daftar susunan pengurus,

d. Rencana program kerja jangka pendek, jangka menengah dan jangka panjang,

e. Neraca atau laporan posisi keuangan,

f. Surat pernyataan bersedia untuk diaudit.

Sebelum dilakukan pengukuhan sebagai LAZ, terlebih dahulu harus dilakukan penelitian persyaratan yang telah dilampirkan. Apabila dipandang telah memenuhi persyaratan tersebut, maka dapat dilakukan pengukuhan.

Selain melakukan pengukuhan, Pemerintah juga melakukan pembinaan kepada LAZ sesuai dengan tingkatan lokasi LAZ tersebut, seperti di pusat oleh menteri agama, di daerah propinsi oleh gubernur atas usul Kepala Kantor Wilayah Departemen Agama Propinsi, di daerah kabupaten/kota oleh bupati/walikota atas usul Kepala Kantor Departemen Agama Kabupaten/Kota, sedangkan di kecamatan oleh camat atas usul Kepala Kantor Urusan Agama.

2. Kewajiban LAZ

Lembaga Amil Zakat (LAZ) yang telah memenuhi persyaratan, dan kemudian dikukuhkan Pemerintah, memiliki kewajiban yang harus dilakukan oleh LAZ, yaitu :

a. Segera melakukan kegiatan sesuai dengan program kerja yang dibuat.

b. Menyusun laporan, termasuk laporan keuangan.

c. Mempublikasikan laporan keuangan yang telah diaudit melalui media massa.

d. Menyerahkan laporan kepada Pemerintah.

3. Pencabutan Pengukuhan LAZ

Lembaga Amil Zakat (LAZ) yang telah dikukuhkan dapat ditinjau kembali, apabila tidak lagi memenuhi persyaratan dan tidak melaksanakan kewajiban sebagaimana dijelaskan dalam point $b$. Mekanisme peninjauan ulang terhadap pengukuhan LAZ dilakukan melalui tahapan pemberian peringatan secara tertulis sampai 3 (tiga) kali dan baru dilakukan pencabutan pengukuhan.

4. Bukti Pembayaran atau Setoran Zakat

Di dalam pasal 12 ayat 1 sampai 4 Keputusan Direktur Jenderal Bimbingan Masyarakat Islam dan Urusan Haji Nomor D/291 Tahun 2000 tentang Pedoman Tekhnis Pengelolaan Zakat, mengatur mengenai bukti setoran zakat.

Ketentuan ini mengharuskan BAZ dan LAZ menerbitkan bukti setoran sebagai tanda terima atas setiap zakat yang diterima. Bukti setoran zakat yang sah tersebut harus mencatumkan hal-hal sebagai berikut:

a. Nama, alamat dan nomor lengkap pengesahan BAZ atau nomor lengkap pengukuhan LAZ,

b. Nomor urut bukti setoran,

c. Nama, alamat muzzaki, dan Nomor Pokok Wajib Zakat (NPWP) apabila zakat penghasilan yang dibayarkan dikurangkan dari penghasilan kena pajak Pajak Penghasilan,

d. Jumlah zakat atas penghasilan yang disetor dalam angka dan huruf serta dicantumkan tahun haul (tahun zakat yang dibayarkan)

e. Tanda tangan, nama, jabatan petugas $\mathrm{BAZ}$ atau $\mathrm{LAZ}$, tanggal penerimaan dan stempel BAZ atau LAZ. 
Bukti setoran zakat yang sah tersebut dibuat dalam rangkap 3 (tiga), dengan rincian sebagai berikut :

a. Lembar 1 (asli), diberikan kepada muzzaki yang dapat digunakan sebagai bukti pengurangan penghasilan kena pajak Pajak Penghasilan;

b. Lembar 2, diberikan kepada BAZ atau LAZ sebagai arsip;

c. Lembar3, digunakan sebagai arsip Bank Penerima, apabila zakat disetor melalui bank.

\section{Sanksi}

Undang-Undang Nomor 38 Tahun 1999 tentang Pengelolaan Zakat, mengatur pula mengenai sanksi. Sanksi ini dicantumkan dalam Pasal 21 ayat 1 sampai 3, yaitu :

a. Setiap pengelola zakat yang karena kelalaiannya tidak mencatat atau mencatat dengan tidak benar harta zakat,infaq,shadaqah, hibah, wasiat, waris dan kafarat sebagaimana dimaksud dalam Pasal 8, Pasal 12, dan Pasal 13 dalam undang-undang ini diancam dengan hukuman kurungan selamalamanya tiga bulan dan/atau denda sebanyak-banyaknya Rp.30.000.000,(tiga puluh juta rupiah).

b. Tindak pidana yang dimaksud pada ayat (1) di atas merupakan pelanggaran.

c. Setiap petugas badan amil zakat dan petugas lembaga amil zakat yang melakukan tindak pidana kejahatan dikenai sanksi sesuai dengan peraturan perundang-undangan yang berlaku.

Antara zakat dan perpajakan memiliki kaitan yang erat. Keterkaitan tersebut sehubungan dengan diakuinya pembayaran zakat yang dilakukan Wajib Pajak dalam negeri untuk dikurangkan terhadap Penghasilan Kena Pajak untuk menghitung pajak yang terutang. Sehubungan dengan adanya keterkaitan seperti diuraikan di atas dan agar prosesnya sesuai dengan ketentuan peraturan perundang-undangan, maka Direktorat Jenderal Pajak (Ditjen Pajak) dengan seluruh jajaran instansi vertikal dibawahnya memiliki fungsi pengawasan.

\section{METODE PENELITIAN}

\subsection{Jenis Penelitian}

Jenis penelitian ini adalah penelitian deskriptif eksploratif. Yaitu penelitian yang mengumpulkan dan menjelaskan fakta-fakta permasalahan yang belaku saat ini untuk dianalisis dan dibahas lebih lanjut. Tipe penelitian ini umumnya berkaitan dengan opini (individu, kelompok, atau organisasional), kejadian, atau prosedur.

\subsection{Populasi dan Sampel}

Populasi penelitian adalah wajib zakat (muzzaki) orang pribadi yang berlokasi di Kota Padang. Sampel penelitian adalah masyarakat Kota Padang yang terutama berprofesi sebagai PNS, wiraswasta dan pegawai swasta, yang diperkirakan mampu dan wajib membayar zakat penghasilan. Metode pengambilan sampel penelitian adalah purposive sampling.

Dalam penentuan jumlah sampel yang digunakan, penelitian ini mengambil sampel dari kuesioner yang dikembalikan oleh responden dengan berdasarkan pertimbangan yang mengacu pada rules of thumb yang dikemukakan oleh Roscoe 
(Sekaran, 2000) yang menyatakan bahwa jumlah sampel yang sesuai untuk penelitian adalah $30<\mathrm{X}<500$.

\subsection{Jenis Data dan Sumber Data}

Data yang digunakan dalam penelitian ini adalah data primer yang diperoleh secara langsung dari responden, yaitu wajib zakat. Metode pengumpulan data yang digunakan dalam penelitian ini adalah metode survey dengan menyebarkan daftar kuesioner penelitian kepada responden, yang meminta pendapat atau menyatakan apa yang dilakukan dan dipahami responden tentang zakat, serta keterkaitannya dengan pajak penghasilan orang pribadi yang juga harus ditunaikan bagi yang memenuhi syarat sebagai wujud tanggung jawab seseorang sebagai warga negara. Wajib zakat yang terpilih sebagai responden diminta untuk mengisi daftar pertanyaan penelitian (kuesioner) secara langsung pada hari yang bersangkutan, atau dia janjikan untuk beberapa hari ke depan.

\subsection{Identifikasi dan Pengukuran Variabel}

Variabel yang akan diukur dalam penelitian ini dibagi atas dua kelompok utama dan satu sub variabel tambahan, yaitu pemahaman terhadap pengetahuan umum pelaksanaan kewajiban pembayaran zakat, dan harapan terhadap ketentuan pembayaran zakat dan pajak penghasilan.

\subsubsection{Pemahaman Terhadap Pengetahuan Umum Pelaksanaan Kewajiban \\ Pembayaran Zakat}

Variabel ini berisikan tentang pengetahuan umum pelaksanaan kewajiban pembayaran zakat, seperti pengertian zakat, jenis zakat, nisab dan tarif zakat penghasilan, penerima zakat, ketentuan pembayaran zakat, pelaksanaan kewajiban zakat oleh responden sendiri dan kaitannya dengan pajak penghasilan. Variabel ini digambarkan dengan 16 item pertanyaan yang terdiri dari 29 subitem jawaban. Jumlah skor jawaban merupakan skor pemahaman responden tentang pengetahuan umum pelaksanaan kewajiban permbayaran zakat.

Untuk operasional pengukurannya, dengan 105 responden, ditentukan tingkat pemahaman dari seluruh responden untuk masing masing item yang ditanyakan. Dengan dimikian ditentukan tingkat pemahaman responden adalah berkisar $0 \%-100 \%$. Apabila semua responden menjawab betul atau setuju, berarti tingkat pemahannya $100 \%$ (sangat paham), dan bila semua menjawab salah/tidak setuju, dikategorikan tidak paham. Dari pemahaman itu dapat dibuat kategori tingkat pemahaman sebagai berikut: (a).Sangat paham $(85 \%-100 \%)$. (b).paham $(70 \%-84 \%)$. (c).Cukup paham $(60 \%-69 \%)$. (d).Kurang paham (50\%-59\%). (e).Tidak paham (di bawah 50\%).

3.4.2 Pemahaman Terhadap Pengelolaan zakat yang efektif (dalam pengumpulan, pendistribusian dan pertanggungjawaban) oleh Pengelola zakat BAZ/LAZ.

Variabel ini berisikan tentang pengetahuan wajib zakat tentang organisasi $\mathrm{BAZ} / \mathrm{LAZ}$, tujuan dan fungsi $\mathrm{BAZ} / \mathrm{LAZ}$, manajemen $\mathrm{BAZ} / \mathrm{LAZ}$ yang baik, dengan menerapkan prinsip-prinsip good governance, serta sejauh mana responden telah membantu BAZ/LAZ dalam penghimpunan zakat, dengan cara menyerahkan zakatnya kepada badan atau lembaga tersebut. Serta harapan-harapan responden terhadap efektivitas pelaksanaan fungsi BAZ/LAZ, serta juga harapannya agar BAZ/LAZ mendorong agar lahirnya Undang_undang yang memperlakukan zakat penghasilan yang dibayar secara resmi melalui BAZ/LAZ diperlakukan sebagai pengurangan beban pajak 
penghasilan yang terhutang. Variabel ini digambarkan dengan 22 item pertanyaan dengan 1 alternatif jawaban Betul/salah.atau dengan pengertian lain, setuju atau tidak setuju. Untuk operasional pengukurannya, sama dengan bagian pertama.

3.5 Teknik Analisis Data

Data penelitian diolah dengan analisis statistik parametrik, berupa nilai statistik dan tabel frekuensi (Santoso, 2001). Adapun langkah-langkah dalam menganalisis data
ini adalah:
1. Melakukar variabel untuk masing-masing kel, yaitu tabel rata-rata (mean) dan nilai tengah (median) menentukan tingkat pemahaman variabel. Nilai-nilai statistik ini digunakan untuk dalam penelitian ini. Nilai rata-rata ini menjumlahkan skor yang diperoleh oleh selurerupakan hasil perhitungan dengan dengan jumlah responden

\subsection{Model Statistik}

Model statistik yang digunakan adalah statistik deskriptif yang merupakan proses transformasi data penelitian dalam bentuk tabulasi sehingga mudah dipahami dan
diinterpretasikan.

\section{4. \\ DATA DAN PEMBAHASAN \\ Proses Pengumpulan Data}

Pengumpulan data dilakukan dengan menyebarkan kuesioner secara langsung ke masyarakat Kota Padang yang merupakan wajib zakat orang pribadi dan dianggap telah
memiliki penghasilan dengan jumlah yang sudah wajib zakat.

Lamanya waktu yang digunakan untuk meyebarkan kuesioner sampai selesai adalah sekitar tiga minggu, yaitu dari tanggal 1 Februari 2011 sampai dengan 31 Maret 2011. Dari keseluruhan (150 ekp) kuesioner yang disebar, ada $115 \mathrm{kembali}$, dan hanya
105 yang bisa digunakan dalam tahap analisis.

\subsection{Demografi Responden}

Dari seluruh sampel yang telah dikumpulkan dan dianalisis, maka respondennya dapat dideskripsikan sebagai berikut:

Responden laki-laki terdiri dari $64 \%$ dan $35,24 \%$ perempuan. Dari tingkat pendidikan, persentase terbesar adalah responden yang berpendidikan sarjana sebesar $41,90 \%$, diikuti dengan tingkat pendidikan SMA/sederajat sebanyak 23,81\%, Diploma Seterusnya dari sudut Jenis Peker $13,33 \%$, sisanya SD dan lain-lain sebanyak $3,81 \%$. oleh Wiraswasta sebesar 26,67\%, Kebanyakan Responden PNS (53,33\%), diikuti

Kemudian, dari jumlah sisanya karyawan swasta dan lain-lain 20\%.

2.000 .000 - Rp $3.000 .000(38,10 \%)$. Rentan, rentang terbesar pada tingkat antara $\mathrm{Rp}$ Rp. 5.000.000 dan kosong (20,95\%), dan sis R 3.000.000 - 4.000 .000 (21,90\%), di atas (19,04\%). Umumnya Responden berstanya berpenghasilan di bawah Rp. 2.000 .000 duda/janda $(8,57 \%)$. Dari sudut berstatus kawin $(91,43 \%)$, belum kawin atau 
penghasilan yang terhutang. Variabel ini digambarkan dengan 22 item pertanyaan dengan 1 alternatif jawaban Betul/salah.atau dengan pengertian lain, setuju atau tidak setuju. Untuk operasional pengukurannya, sama dengan bagian pertama.

3.5 Teknik Analisis Data

Data penelitian diolah dengan analisis statistik parametrik, berupa nilai statistik dan tabel frekuensi (Santoso, 2001). Adapun langkah-langkah dalam menganalisis data
ini adalah:

1. Melakukan tabulasi dari jawaban-jawaban yang diperoleh dari kuesioner untuk setiap
variabel

2. Menghitung nilai statistik, yaitu tabel rata-rata (mean) dan nilai tengah (median) untuk masing-masing kelompok variabel. Nilai-m menentukan tingkat pemahaman sampel Nilai-nilai statistik ini digunakan untuk dalam penelitian ini. Nilai rata-rata terhadap variabel-veriabel yang diajukan menjumlahkan skor yang diperoleh oleh selurerupakan hasil perhitungan dengan 3.6 dengan jumlah responden

deroleh oleh seluruh responden, kemudian membaginya

3.6 Model Statistik

Model statistik yang digunakan adalah statistik deskriptif yang merupakan proses transformasi data penelitian dalam bentuk tabulasi sehingga mudah dipahami dan
diinterpretasikan.

\section{4. \\ Pralisis DATA DAN PEMBaHASAN \\ Proses Pengumpulan Data}

Pengumpulan data dilakukan dengan menyebarkan kuesioner secara langsung ke masyarakat Kota Padang yang merupakan wajib zakat orang pribadi dan dianggap telah memiliki penghasilan dengan jumlah yang sudah wajib zakat.

Lamanya waktu yang digunakan untuk meyebarkan kuesioner sampai selesai adalah sekitar tiga minggu, yaitu dari tanggal 1 Februari 2011 sampai dengan 31 Maret 2011. Dari keseluruhan (150 ekp) kuesioner yang disebar, ada $115 \mathrm{kembali}$, dan hanya
105 yang bisa digunakan dalam tahap analisis.

\subsection{Demografi Responden}

Dari seluruh sampel yang telah dikumpulkan dan dianalisis, maka respondennya dapat dideskripsikan sebagai berikut:

Responden laki-laki terdiri dari $64 \%$ dan $35,24 \%$ perempuan. Dari tingkat pendidikan, persentase terbesar adalah responden yang berpendidikan sarjana sebesar $41,90 \%$, diikuti dengan tingkat pendidikan SMA/sederajat sebanyak $23,81 \%$, Diploma Seterusnya dari suduter \& Doktor $13,33 \%$, sisanya SD dan lain-lain sebanyak $3,81 \%$. oleh Wiraswasta sebesar $26,67 \%$, jaan Kebanyakan Responden PNS (53,33\%), diikuti

Kemudian, dari ju,

2.000 .000 - Rp $3.000 .000(38,10 \%)$ Rhasilan, rentang terbesar pada tingkat antara $\mathrm{Rp}$ Rp. 5.000.000 dan kosong (20,95\%), Rentang Rp 3.000.000 - 4.000 .000 (21,90\%), di atas (19,04\%). Umumnya Responden dan sisanya berpenghasilan di bawah Rp. 2.000.000 duda/janda $(8,57 \%)$. Dari sudut berstatus kawin $(91,43 \%)$, belum kawin atau 
lebih dari 4 orang $36,19 \%$, Tanggungan 4 orang $33,33 \%$, sisanya tanggungan di bawah 4 orang $30,47 \%$.

Selanjutnya responden yang selalu menunaikan zakat mencapai 92\%, Responden yang membayar zakat penghasilan/profesi $93,33 \%$. Sedangkan dari sudut tempat responden membayar zakat, didominasi oleh responden yang membayar zakat langsung kepada mustahiq $(49,52 \%)$, membayar melalui BAZ/UPZ tempat respinden bekerja $(30,48 \%)$, melalui masjid $(12,38 \%)$ dan melalui LAZ $(7,26 \%)$. Dari sudut waktu menunaikan pembayaran zakat, Moyoritas responden telah membayar zakatnya pada setiap menerima pendapatan (bulanan) sebesar $53 \%$, dan setiap tahun $34,29 \%$, sisanya setiap tiga bulan atau cara waktu lain. Terakhir dasar yang digunakan dalam menentukan besarnya jumlah zakat yang dibayar, Sebagian besar responden telah menghitung zakatnya atas dasar Jumlah penghasilan yang diperoleh (43\%), dasar pendapatan bersih $(29,52 \%)$, dan sisanya menghitung zakatnya atas penghasilan setelah dikurangi belanja hidup dan atau juga hutang / kewajiban yang harus ditunaikan saat itu.

4.3. Pemahaman Wajib Zakat terhadap Ketentuan Zakat dan Undang-Undang Pajak Penghasilan dalam Kaitan Pembayaran Zakat Penghasilan

Sebagaimana dijelaskan pada bab III, pemahaman wajib pajak orang pribadi terhadap ketentuan zakat dan PPh ini mencakup dua variabel utama, yaitu pemahaman terhadap pengetahuan umum zakat penghasilan dan pajak penghaslan (PPh) dan pelaksanaan kewajiban zakat dan $\mathrm{PPh}$ oleh wajib zakat dan sekaligus wajib pajak, serta pemahaman terhadap pengetahuan umum pelaksanaan kewajiban pembayaran zakat.

Pada penelitian ini, dari jawaban semua responden mengenai berbagai hal yang berkenan dengan pemahaman responden terhadap zakat dan pajak, lebih jauh dapat dikategorikan menjadi lima tingkat, yaitu sangat paham, paham, cukup paham, kurang paham dan tidak paham.

\subsection{Pemahaman terhadap Pengetahuan Umum zakat dan Pajak Penghasilan serta pelaksanaan kewajiban zakat}

Pemahaman tentang pengetahuan umum zakat dan pajak penghasilan dan pelaksanaan kewajiban wajib zakat diukur dengan 16 pertanyaan dengan 29 item dengan $\%$ tingkat pemahaman berada diantara $0 \% \mathrm{~s} / \mathrm{d} 100 \%$. Tingkat pemahaman responden terhadap kewajiban zakat dan pajak penghasilan (PPh) adalah sebesar 74\% dengan kategori paham.

Sedangkan tingkat pemahaman untuk masing-masing pertanyaan yang dijukan, diperoleh \% tingkat pemahaman yang tertinggi adalah pada pertanyaan yang ke dua (2) yang menanyakan " zakat wajib dibayarkan oleh orang yang mampu sesuai dengan ketentuan zakat dengan 5 tingkat pemahaman 99\% dengan kategori Sangat Paham. Diikuti oleh pertanyaan yang ke 6 , dengan pernyataan "Tarif zakat pendapatan adalah $2,5 \%$ dari pendapatasn sebagai dasar perhitungan zakat, yaitu dengan tingkat $\%$ pemahaman sebesar 97\% dengan kategori "Sangat Paham". Demikian juga seterusnya untuk pertanyaan no 8 juga dengan tingkat \% pemahaman 97\% (Sangat Paham). Pertanyaan no $11(95 \%)$, pertanyaan no. 10 (94\%) dan lain-lain.

Sebaliknya tingkat pemahaman yang terendah adalah pada pertanyaan no. 12, yang berbunyi "Dalam melakukan pembayaran zakat pendapatan, seharusnya menggunakan surat setoran zakat" dalam hal ini sebegian besar responden tidak setuju, 
hal ini juga sejalan dengan jawaban responden pada bagian demografi responden, yaitu sebahagian responden melakukan pembayaran kewajiban zakatnya langsung kepada mustahik (50\%), melalui UPZ tempat rsponden bekerja (30\%) dan juga melalui masjid $(12 \%)$. Jadi tidak diperlukan atau tidak diberikan bukti penyetoran. Selanjutnya tingkat pemahaman yang rendah dengan jawaban tidak setuju, adalah mengenai data yang harus dicantumkan pada surat setoran zakat, yang menurut responden tidak perlu mencantumkan NPWP, besarnya pajak penghasilan yang terhutang. Pada hal kalau pembayaran zakat melalui $\mathrm{BAZ}$ atau $\mathrm{LAZ}$, menurut ketentuan harus mencantumkan datadata yang demikian.

\subsection{Pemahaman Terhadap Pengelolaan Zakat yang Efektif oleh Pengelola Zakat \\ BAZ / LAZ}

Pemahaman terhadap pengelolaan zakat yang efektif oleh Pengelola zakat yaitu Badan Amil Zakat (BAZ) atau Lembaga Amil Zakat (LAZ) diukur dengan 22 pertanyaan, dengan nomor pertanyaan berurutan dari kelompok pemahaman umum zakat (no. $17 \mathrm{~s} / \mathrm{d}$ 38), terutama peraturan-peraturan berkenaan dengan BAZ/LAZ, fungsi dan tujuan adanya BAZ/LAZ, dengan $\%$ tingkat pemahaman berada diantara $0 \% \mathrm{~s} / \mathrm{d} 100 \%$. Dari data yang terkumpul, diperoleh tingkat pemahaman responden secara rata-rata cukup tinggi yaitu $82 \%$ denga kategori Paham.

Sedangkan tingkat pemahaman untuk masing-masing pertanyaan yang dijukan, diperoleh \% tingkat pemahaman yang tertinggi adalah pada pertanyaan yang no 27 dan no 34 dengan \% tingkat pemahaman sebesar 93\% (sangat paham), yang masing-masingnya menanyakan: " BAZ/LAZ harus selalu mensosialisasikan peran penting zakat sebagai cara untu pengentasan kemiskinan" dan "BAZ/LAZ harus mampu mengelola zakat secara profersional, jujur, ikhlas, dan betanggung jawab (akuntanbel).

Selanjutnya diikuti oleh pertanyaan no. 33 dengan pertanyaan yang berbunyi “ $\mathrm{BAZ/LAZ} \mathrm{harus} \mathrm{mampu} \mathrm{melaksanakan} \mathrm{akuntansi} \mathrm{zakat} \mathrm{yang} \mathrm{kuat} \mathrm{dan} \mathrm{andal,} \mathrm{sehingga}$ dapat menyusun laporan keuanagan secara periodik (bulanan, triwulan dan tahunan) dengan\% tingkat pemahaman $91 \%$ atau dengan kategori "Sangat Paham", kemudian diikuti lagi oleh pertanyaan no. 26 dan 35, dengan pertanyaan yang bebunyi " BAZ/LAZ perlu membuat buku pedoman / panduan-panduan praktis mengenai tata cara pelaksnaan zakat yang harus dibayarkan oleh wajib zakat atau muzzaki" dan "BAZ/LAZ harus mampu membuat dan menyampaikan laporan keuangan periodik secara terbuka kepada publik, minimal berupa laporan arus kas dan laporan posisi keuangan.(neraca) sesuai dengan standar akuntansi keuangan yang berterima umum" kedua-dua pertanyaan ini hampir seluruh responden setuju, dengan \% tingkat pemahaman $90 \%$ dengan kategori Sangat Paham.

Sebaliknya \% tingkat pemahaman yang terendah didapati pada pertanyaan no. 22, yang menyatakan " $\mathrm{BAZ} / \mathrm{LAZ}$ harus memproritaskan pendistribusian zakat untuk kegiatan dan usaha yang produkrif" dengan tingkat pemahaman $62 \%$ atau dengan kategori "cukup paham". Selanjutnya diikuti dengan pertanyaan no. 23, yang menyatakan bahwa " BAZ/LAZ harus melakukan pembiayaan untuk kegiatan-kegiatan pelatihan keterampilan, sehingga dapat memberdayakan masyarakat" dengan $\%$ tingkat pemahaman sebesar $67 \%$ atau dengan kategori pemahaman "cukup paham". 


\section{6. Pembahasan Hasil Penelitian}

Dari hasil analisis data diperoleh hasil yang menyatakan secara rata-rata masyarakat telah memahami kewajiban zakat secara lebih baik, namun pelaksanaan pembayaran kewajiban zakat tersebut, masih dilakukan secara tradisonal, yaitu dengan menyerahkan langsung kepada orang yang berhak menerima zakat (mustahik) cara seperti ini mencapai $50 \%$ responden melakukannya. Hanya 7,6 \% responden yang melakukan pembayaran zakatnya melalui $\mathrm{LAZ}$, dan $30 \%$ responden melaksanakan kewajiban zakatnya melalui pemotongan gaji oleh UPZ-BAZ yang ada di kantor tempat ia bekerja.

Fakta yang ditemukan dalam peneltian ini, diduga berkaitan erat dengan sifat kekeluargaan yang cukup tinggi di Minangkabau, hal ini juga sesuai dengan ajaran Islam, bahwa setiap orang harus memperioritaskan terlebih dahulu untuk membatu keluarga terdekat yang membutuhkan, kemudian baru kepada keluarga jauh dan orang lain.

Ada beberpa kelemahan dari cara menyerahkan zakat langsung kepada mustahik, yaitu, kegunaan zakat terbatas hanya untuk tujuan pemenuhan kebutuhan pokok/konsumtif, pembayaran zakat oleh muzzaki kurang terukur, dan kemungkinan tidak tuntas. Sebaliknya bagi mustahik, penggunaan atau pemakaiannya juga tidak terarah, karena dalam waktu tertentu ia hanya dapat terlalu sedikit, sementara pada waktu lain, ia mungkin mendapatkan cukup banyak, dari banyak orang atau muzzaki yang kebetulan sama-sama bersakat kepadanya pada waktu itu. Pada waktu seorang mustahik memperoleh penerimaan zakat yang berlebihan ini, juga dapat mendorong ia berbelanja yang lebih besar, melebihi kebutuhannya, tidak terarah, dan kemungkinan juga mubazir, atau menggunakannya untuk kegiatan-kegiatan yang tidak bermanfaat dan sebagainya.

Akan bebeda halnya, kalau zakat dibayarkan melalui badan atau lembaga resmi pengelola zakat, yaitu BAZ/LAZ, yang dapat melakukan pembinaan terhadap masyarakat tidak mampu yang berhak menerima zakat (mustahik), dengan cara memberikan dana zakat yang cukup untuk melakukan suatu usaha yang produktif. Sehingga yang bersangkutan tidak selalu menggantungkan hidupnya dari pemberian zakat oleh keluarga/atau orang yang berbaik hati kepadanya. Karena dengan pemberian modal kerja sejumlah tertentu oleh BAZ/LAZ, ia dapat melakukan usaha produktif yang dapat mendatangkan hasil atau pendapatan baginya secara terus menerus, yang dapat mencukupi kebutuhan hidupnya dan keluarganya. Walaupun dalam jangka waktu tertentu, ia tetap membutuhkan bantuan dan bimbingan dari manajemen BAZ/LAZ. Namun ketergantungan ini tidak akan berlangsung lama, setelah lewat waktu pembinaan ia sudah bisa mandiri, dan tidak tertutup kemungkinan, beberapa waktu kemudian iapun menjadi orang yang mampu membayar zakat (muzzaki).

Jadi dengan pebayaran zakat melalui Badan-Badan Amil Zakat (BAZ) atau Lembaga-Lembaga Amil Zakat, tentunya dana yang terhimpun jadi lebih besar, lalu dikelola dengan baik secara efektif, dan disalurkan kepada lebih banyak orang secara terarah, terencana, terpantau dan terawasi dengan baik, maka dengan pemberian modal usaha, pelatihan yang praktis, untuk membuka usaha produktif tertentu, tentunya seorang mustahik dapat diberdayakan, dan pada suatu ketika nanti ia akan menjadi muzzaki. Pola yang semacam ini akan bergulir terus menerus, dan akan mempunyai dampak mpositif yang lebih luas dan erata, sehingga betul-betul zakat dapat difungsikan sebagai alat pengentasan kemiskinan.Insya Allah, demikian. 


\section{KESIMPULAN}

Berdasarkan keseluruhan pembahasan yang dilakukan pada bab terdahulu, selanjutnya dapat ditarik beberapa butir kesimpulan sebagai berikut:

1. Secara demografik dan kultural, bangsa Indonesia, khususnya masyarakat Kota Padang/Minangkabau adalah beragama Islam dan beradat, dengan Filosopi “ Adat Basandi Syarak, Sarak Basandi Kitabullah" / ABS-SBK. Dengan Filosopi demikian, secara kultural kewajiban berzakat, berinfak, dan bersedekah di jalan Allah telah mengakar kuat dalam tradisi kehidupan di Minangkabau.

2. Masyarakat Wajib Zakat (muzzaki) di Kota Padang tergolong orang-orang yang paham terhadap ketentuan zakat dan UU perpajakan yang berlaku, dengan persentase tingkat pemahaman sebesar 79\% (paham).

3. Pengamalan untuk menunaikan kewajiban zakat bagi masyarkat Kota Padang, mencapat persentasi tingkat pemahaman yang tinggi, yaitu mencapat tingkat $97 \%$, dengan jenis zakat pendapatan/profesi/perdagangan sebesar $98 \%$, kedua keadaan ini termasuk kategori sangat paham.

4. Pemahaman masyarakat terhadap manfaat dan efektifitas pembayaran zakat melalui BAZ/LAZ cukup tinggi, namun dalam realisasinya masyarakat kota Padang, secara moyoritas melakukan pembayaran zakatnya langsung kepada mustahik, dan belum melalui Badan atau lembaga zakat yang ada.

5. Pemamahan dan harapan masyarakat cukup tinggi agar organisasi pengelola zakat, yaitu BAZ / LAZ dapat mengelola zakat dengan baik, efektif berdasarkan prinsipprinsip good organizatio covernance. Namun masyarakat belum sepenuhnya mendukung pelaksanaan program kerja BAZ/LAZ dengan menyerahkan zakatnya melalui BAZ/LAZ yang ada saat ini.

6. Pemahaman masyarakat masih redah terhadap adanya Undang-Undang no 38 Tahun 2008 tetang Pajak Penghasilan yang memperlakukan zakat pendapatan yang telah dibayarkan sebagai pengurangan atas penghasilan kena pajak (PTKP). Hal ini tercermin dari kurangnya pemahaman masyarakat, agar perlu adanya bukti setoran zakat, yang memuat data-data untuk pelaksanaan kewajiban Pajak Penghasilan (PPh).

7. Di samping masyarakat sangat menginginkan agar BAZ/LAZ senantiasa mendorong masyarakat untuk menunaikan zakat, dengan cara mengeluarkan panduan-panduan praktis tetang pelaksanaan kewajiban zakat, BAZ/LAZ juga diharapkan dapat menjadi Instisi pendorong untuk lahirnya Undang-Undang atau ketentuan, yang memperlakukan zakat yang dibayarkan melalui BAZ/LAZ diperlakukan sebagai pengurangan atas jumlah beban Pajak Penghasilan (PPh) yang terhutang.

8. Masyarakat wajib zakat (muzzaki) yang juga membayar pajak kebanyakan tidak terikat dengan adanya peraturan pajak yang sudah ada, tetapi lebih kepada kepatuhan terhadap agama dengan adanya kewajiban membayar zakat sembari mengharap pahala dari Allah SWT sehingga kebanyakan wajib pajak tidak membayar zakat ke Badan Amil Zakat ataupun Lembaga Amil Zakat yang dibentuk dan disahkan pemerintah.

9. Dengan adanya pengelolaan zakat yang lebih profesional dari Badan Amil Zakat dan atau Lembaga Amil Zakat dapat meningkatkan pemahaman wajib zakat untuk 
menunaikan kewajiban membayar zakat di kedua lembaga tersebut sehingga dapat membantu peningkatan kesejahteraan masyarakat dan dapat mendorong pemberdayaan masyarakat dari mustahik untuk menjadi muzzaki.

Berdasarkan beberapa keterbatasan yang telah diungkapkan, penulis menyusun saran untuk penelitian selanjutnya, yaitu:

1. Penelitian ini diharapkan dapat memberikan kontribusi pada literatur ilmu pengetahuan, terutama yang berhubungan dengan masalah zakat dan perpajakan sesuai dengan tujuan yang diharapkan ketika penelitian ini disusun.

2. Untuk penelitian selanjutnya juga bisa mengembangkan variabel pemahaman kewajiban perpajakan dan berzakat wajib pajak oran gpribadi dengan variabel lain yang relevan.

3. Untuk penelitian lanjutan disarankan aagar penyusun daftar kuesioner dengan alternatif jawaban dengan kategori lebih rinci yaitu mulai, sangat paham, paham, cukup paham, kurang paham, dan tidak paham.

Dengan diperolehnya hasil penelitian, tentunya Badan Amil Zakat dan Lembaga Amil Zakat (BAZ/LAZ) lebih menyadari untuk dapat menunjukkan program kerja yang lebih efektif, efisien dan lebih merata kepada masyarakat. Sehingga masyarakat akan memperoleh tingkat kepercayaan yang tinggi kepada BAZ/LAZ, dan berusaha mendukung untuk lebih mengsuseskan program kerja yang lebih baik dan lebih efektif tersebut. Masyarakat akan berlomba untuk menyerahkan zakatnya kepada BAZ/LAZ yang ada, apalagi lagi kalau BAZ atau LAZ sudah berusaha pula secara maksimal untuk mengajukan usulan kepada pihgak yang berwenang (DPR \& Pemerintah) agar melahirkan aatau membuat Undang-undang atau aturan yang memperlakukan pembayaran zakat pendapatan/profesi/perdagangan secara resmi oleh muzzaki kepada BAZ/LAZ sebagai pengurangan atas jumlah kewajiban pajak penghasilan (PPh) yang terhutang untuk tahun pajak yang bersangkutan.

\section{DAFTAR PUSTAKA}

Astuti, Regina Dwi. 2007. Analisis Tingkat Pemahaman Wajib Pajak Orang Pribadi terhadap Peraturan Pelaksanaan Kewajiban Perpajakan di Kota Padang. Padang : Skripsi Sarjana Fakultas Ekonomi Universitas Andalas

Azka, Abu dan Lukman Muhammad Baga. 1997. Fiqih Zakat : Sari Penting Kitab Dr. Yusuf Al-Qardhawy. Bogor: Islamic Network.

Darussalam, Danny. 2003. Perlakuan Zakat atas Penghasilan dalam Penghitungan Penghasilan Kena PajakPajak Penghasilan. http://dannydarussalam.com

Desi, Yusfi. 2006. "Analisa Tingkat Pemahaman Wajib Pajak Badan dan Fiskus Terhadap Perencanaan Pajak dan Penggelapan Pajak di Wilayah KPP SumbarRiau (Studi Kasus : Kota Padang)". Padang : Skripsi Sarjana Fakultas Ekonomi Universitas Andalas.

Direktorat Jenderal Pajak, 2011. Zakat dan Pajak Sama-Sama Wajib. http://banjarmasin.tribunnews.com/

Indriantoro, Dr. Nur, M.Sc., Ak. dan Drs. Bambang Supomo, M.Si., Ak. 1999. Metodologi Penetian Bisnis. Yogyakarta : BPFE. 
Meryani, Andina. 2010. Akhirnya, Pemerintah Setujui Zakat sebagai Pengurang Pajak. http://economy.okezone.com/

Muhammad, 1994. Zakat Profesi Wacana Pemikiran dalam Fiqih Kontemporer. Jakarta : Salemba Diniyah.

Nahar, Syamsun. 2008. Panduan Praktis Menghitung Zakat. Jakarta : Baitul Maal Abdurrahman bin Auf.

Putra, Tri Rezeki Perdana. 2009. "Analisis Tingkat Pemahaman Wajib Pajak Orang Pribadi terhadap Peraturan Pelaksanaan Kewajiban Perpajakan di Kota Solok. Padang : Skripsi Sarjana Fakultas Ekonomi Universitas Andalas.

Resmi, Siti. 2008. Perpajakan, Teori, dan Kasus. Edisi Keempat. Jakarta : Salemba Empat.

Rosdiana, Haula dan Rasin Tarigan. 2005. Perpajakan, Teori, dan Aplikasi. Jakarta : Raja Grafindo Persada.

Santoso, Singgih. 2001. Statistik Parametrik. Jakarta : PT Gramedia Pustaka Utama.

Surur, Naharus. 2001. Zakat dan Peranannya dalam Krisis. PKPU Online : http://pkpu.or.id

Syafrudin, Amir. 2010. Zakat sebagai pengurang pajak. http://bicarapajak.blogspot.com

Syarifudin, Nahar, S.H. 2004. Badan Amil Zakat dan Lembaga Amil Zakat, Relevansinya terhadap Pajak. http://pkpu.or.id 